\title{
An Analysis of Students' Error on the Use of Simple Preposition in Narrative Composition Made by the Eleventh Grade of SMK Tunas Karya Pekanbaru
}

\author{
Muhammad Taufik Ihsan ${ }^{1}$ \\ Faculty of Education and Teacher Training, \\ State Islamic University of Sultan Syarif Kasim Riau, \\ Pekanbaru, Riau, Indonesia \\ muhammad.taufik.ihsan@uin-suska.ac.id ${ }^{1}$
}

\begin{abstract}
The purpose of this research is to analyze the eleventh grade students' error in using preposition in writing narrative text at SMK Tunas Karya Pekanbaru. This study was a descriptive research, the subject of this research was the eleventh grade students' of SMK Tunas Karya Pekanbaru while the object of this research was students' error in using preposition in writing narrative text. The researcher used purposive sampling technique to take the sample, there were 35 students as sample from 96 students. To collect the data the researcher used test. The test was conducted to know what types of errors were made by the students when they used preposition in writing narrative text. The result of the error analysis process showed that students committee error into three types: omission, insertion and selection. From the calculation of the data, error of insertion is the most frequent errors that done by the eleventh grade students of SMK Tunas Karya Pekanbaru with the percentage 41.9\%. Moreover it is followed by error of omission with percentage $30.9 \%$, and error of selection with percentage $27.1 \%$.
\end{abstract}

Keywords: Analysis, Error, Preposition, Narrative Text.

\section{INTRODUCTION}

Errors in writing is the error which is innpropriate with certain grammar. Grammar is always be considered as an essential substance in teaching english especially in english as a foreign and second language generally. Learning grammar is something difficult to the students because there are many rules in grammar that cannot be ignored, the common errors often find in students' writing is the error on preposition. This statement is supported by (Sudhakaran, 2015) who says that one major grammar observe in both students speech and writing in is the error of preposition.

In this case, the researcher only focuses on one part of grammar, preposition. (A Seaton, 2007) define preposition as a word that connects one thing with another, showing how they are related. They assert that it is usually followed by a noun or pronoun. According to (Mutmainna, 2014, p. 3), prepositions can be categorized on the basis of their functions.

There are many types of text writing. They are descriptive, narrative, expository, and so on. From all those 
texts, narrative is easier to be analyzed and the students always made error in narrative composition. As explained by (Yahya, A., Ishak, H. B., Zainal, Z., Faghat, L. J., \& Yahaya, N, 2012) more errors were made in the narrative compositions compared to the descriptive compositions. In narrative text there are several kinds of prepositions. They are preposition of position, preposition of direction and preposition of time. Preposition is a word which is placed in front of noun or pronoun to show relationship of position, direction, and time.

SMK Tunas Karya Pekanbaru is one of the Vocational High School in Pekanbaru. The School is located on street Tuanku Tambusai. Narrative writing is a kinds of writing which becomes one of the lesson which is taught in Vocational High School based on Kurikulum Tingkat Satuan Pendidikan (KTSP) 2006.

Based on researcher's preliminary study at SMK Tunas Karya Pekanbaru, when the researcher did the preliminary research at SMK Tunas Karya on 02 February 2019. The researcher found the research problem based on the interview with English Teacher of SMK Tunas Karya Pekanbaru, Mrs Jamiatun. The teacher said that the students had some difficulties to write paragraphs, especially the paragraphs that described past event or narrative text. Furthermore, the students was hard to choose the types of verb when making paragraphs in past even, such as narrative text, and also they were difficult to understand how to use the right preposition in compositions they write. In preliminary research, the writer also got some data of English study score from English teacher of SMK Tunas Karya Pekanbaru, as a result of some of the students got low in narrative composition. There were more students who got low scores below the criteria of minimum mastery (KKM) at the school, which are 70. There were 38 students or $39,5 \%$ out of 96 students get the scores above the criteria of minimum Mastery (70). In other words there are 58 students or $60,5 \%$ of 96 students are able to have good achievement in english subject.

Based on identification of the problem above, it is important for researcher to limit the problem discussed in this study. In this research, the researcher limit the problem focused on error analysis students in using preposition in writing narrative composition of the eleventh grade students at Vocational High School Tunas Karya Pekanbaru. The preposition in this research includes preposition of position, direction, and time.

Based on the problem depicted in the background, the researcher formulates some research questions as follows: What are the types of errors do the students make in using preposition in writing narrative composition?

\section{LITERATURE REVIEW}

\section{a. The Definition Of Error Analysis}

Error analysis is tool to help the researcher checked the grammatical error that made students especially using tenses in narrative text. According to (Hourani, 2008, p. 16) )," Error analysis is an essential source of information to teachers. It provides information on students' errors which in turn helps teachers to correct students' errors and also improves the effectiveness of their teaching".It means that, error analysis is very important because the researcher 
would to the types of errors done by students of using past tense in writing narrative text and the factors that influence their errors. Errors is very usual in writing paragraph or essay, so errors analysis is needed by teacher to correct the student's essay. In addition (Yang, 2010), error analysis is the process of determining the incidence, nature, causes and consequences of unsuccessful language. The errors can help the teacher in teaching and learning process because the teacher can observe the reason or why the learners do the errors. Error analysis will show teachers some problems facing by the students.

In addition, it is necessary to discuss error analysis for teaching English as a foreign language. English teachers should to know error analysis because it becomes a useful key to understanding the process of foreign language. They should to know how the target language is learnt and what the best strategy the learners done in order to master the target language. After conducting the study of error, the teachers can improve their teaching method and attempt to find some answers or solutions to solve some problems faced by their students.

From the explanation above, the writer can conclude that error analysis is methodology for investigating students' competence of the second language acquisition or a foreign language. It describes students' inter language and can be used to identify the possible mistakes or errors that are made by students.

\section{b. Technique of Analyzing the Error}

In analyzing students' errors, there are some steps to be followed. According to (Hasanah, 2017), there are five steps in analyzing students' errors, they are: collection of sample of learner language, identification of errors, description of errors, explanation of errors and evaluation of errors.

1) Collection of Sample of Learner Language

The first step of analyzing the errors is collection of sample. In this step, the researcher must decide a number of students which is being sample for the research. Then, they will be given regular examination in order to get data.

2) Identification of errors

In this step the writer must identify error from data collection. For identifying error, the writer must compare the sentence that was produced by students to the correct sentence in the target language.

3) Description of Errors

After identifying errors, the next step is description of errors. In this step, all errors that have been identified, then they would be classified into the types of errors.

4) Explanation of Errors

This step will explain why errors can be happened. This explanation related on the sources of errors. The researcher may consider the student' error whether the error because of interlingual transfer, intralingual transfer, context of learning, or communication strategies.

5) Evaluation of Errors

In this step, the writer must decide the criteria of errors which will be corrected because some errors can be considered more serious than other. The aim of evaluating errors is to distinct which errors will be corrected so the learner, which made an error, will not be stress of getting correction.

\section{c. Preposition Error}

The error is unavoidable in the learning process of English as a 
foreign language for Indonesian learners, especially the error on the use of preposition. According to (Mustafa, F., Kirana, M., \& Bahri, S., 2017), errors in preposition can be regarded as lexical errors since the errors affect meaning and hence students will correct those errors by the time they have an adequate vocabulary.

Since there are many prepositions in English, these errors are due to incomplete learning of the rules. It takes time for the students to learn the usage of the large number of prepositions. (Arjan A, Abdulla N, H \& Roslim N, 2013) stated that the confusion normally happens when the learners are uncertain about which prepositions to be used in almost similar contexts. Addition, most English prepositions have several different functions. Furthermore, (Murshidi, G., 2014, p. 173) suggested that the different parts of speech in sentences could confuse the learners and let them make some prepositional errors such as omission, addition or selection the wrong preposition in English.

\section{d. Narrative Composition}

Writing is the process in which someone tries to produce something in written form, in this case in certain genre of text or composition. A composition is a piece writing that consists of one or mere paragraph. According to Hamzah $(2009$, p. 3), one of the distinctive types of writing is a composition which is defined as a piece of writing made up of one or more paragraphs talking about a definite theme or subject. Whereas, narrative paragraph is paragraph that explain background, plot, and characters involved in a narrative composition.

Coffman and Reed (2010, p. 5) stated that narratives have been described as having several common components including a setting, plot (series of episodes based on goals, attempts, outcomes), resolution or story ending. Then, narrative becomes part of how people understand the world they live in and they serve as a way of communicating that understanding to others. As stated by Meyers (2005, p. 52), narrative is one of the most powerful ways of communicating with others.

According to (Negrila AMC \& Ionel A, 2012), a narrative text tells an imaginary story, although some narratives may be based on facts. They assert that narratives are written in many different forms and each form has distinctive characteristics.

Regarding, the generic structure of narrative text; (Anderson, M. \& Anderson K, 2003) explained three steps in constructing a narrative are. They are orientation, complication, and resolution.

a) Orientation, the writer tells the audience who is in the story, when it is happening where it is happening and what is happening.

b) Complication, the writer tells about something that will begin a chain of events.

c) Resolution is the ending of the story, it shows how the characters deal with the problem.

According to (Negrila AMC \& Ionel A, 2012), there are many types of narrative texts: folktales, fairytales, fables, myths, legends, science-fiction, short stories, picture-story books and ballads, but also narration of past events, past experiences, incident reports, trip reports and other forms of military writing that may include narration etc. Basically, writing in narrative composition is to write down what is 
seen, what is heard, and what is perceived by writer. (Gaetz., Lynne., \& Phadke, S., 2011) argue that in narrative composition, the writer creates a story that will not only entertain the readers, but will have a concluding point or message. Because narrative composition are the telling of personal stories, the writer is able to be more creative with the structure and organization. From the above explanation, it can be concluded that the narrative composition is the composition that attempts to explain the chain of past events, by observing the time sequence so that the reader as though experiencing the event.

\section{METHOD}

In this research, the researcher used descriptive design. The researcher described and analyzed the kind of errors in the use preposition of position, direction and time. Thus, the researcher described and analyzed the types of preposition errors by students writing in narrative text. Acccording to (Cholid Narbuko dan Abu Achmadi , 2013), descriptive research is a research trying to express the problems existing now based on the data. This research has one variable, it was analyzing the errors made by the students of the eleventh grade at SMK Tunas Karya Pekanbaru. In this research, the researcher collected the data from the students' narrative text writing and investigated them whether the students used correct preposition or not, and identified the students' errors.

Participants in this research, it is called purposive sampling. Because, the researcher wants to get depths understand about used writing test. The researcher used a written test to investigate the students' errors on the use of preposition in writing narrative composition was selected to make the discussion which is focused on the maintopic. the researcher explained a brief explanation to remind the students about narrative text that they had studied. Then, the researcher asked the students to write narrative text based on the title that given by the researcher. The titles were: (1) Sangkuriang (2) Malin Kundang (3) Danau Toba (4) Timun Mas.

\section{FINDINGS AND DISCUSSION}

To analyze preposition errors in narrative composition of the students, the procedures of error analysis proposed by Ellis (1997) were followed. There were three steps of error analysis. They were; identifying the errors, describing the errors and explaining the errors. Furthermore, in this chapter the researcher presents the recapitulation data based on raters identified about a test of students' works on producing writing of Narrative texts which have been collected by the students at the eleventh grade of SMK Tunas Karya Pekanbaru.

In this research, the researcher used two raters to analyze errors of the students' writing on use of preposition. Thus, the researcher made the data averages of errors on the use of preposition to analyze the most frequent errors done by the eleventh grade students of SMK Tunas Karya Pekanbaru.

Table VI. 3

The Recapitulation of Error Types, Frequency and its Percentage

\begin{tabular}{|l|l|l|l|}
\hline No & Types of Error & $\begin{array}{c}\text { Total of } \\
\text { Error }\end{array}$ & $\begin{array}{c}\text { Percentage } \\
(\%)\end{array}$ \\
\hline 1 & OMISSION & 73 & $30.9 \%$ \\
\hline 2 & INSERTION & 99 & $41.9 \%$ \\
\hline 3 & SELECTION & 64 & $27.1 \%$ \\
\hline
\end{tabular}

Based on the calculation above, it can be concluded that the total errors of omission are 73 errors or $30.9 \%$, 
errors of insertion are 99 errors or $41.9 \%$, error of selection are 64 errors or $27,1 \%$. From the calculation of the data, error of insertion is the most frequent errors that done by the eleventh grade students of SMK Tunas Karya Pekanbaru with the percentage $41.9 \%$. Moreover, it is followed by error of omission with percentage $30.9 \%$, and error of selection with percentage $27.1 \%$.

\section{a. The description of Errors}

This study aimed at finding the error on the use of preposition in narrative compositions made by the eleventh grade students of SMK Tunas Karya Pekanbaru. After collecting the data from the students, researcher analyzed and identified student's sentences that contained preposition errors based on average errors that have been identified by the raters on each error types on the use of preposition.

Based on the data average by raters, there were 236 preposition errors found in students' narrative compositions. The researcher provide all of those sentences in the table VI.3 completed with the error types of each preposition. The errors were classified based on Jha's classification (1991), they were; omission, insertion and selection. There were 73 errors were found in omission, 99 errors were found in insertion and 64 errors were found in selection.

\section{b. The Explanation of Errors}

There are 35 students made errors in omission which the totals of error are 73 errors or $30.9 \%$. These errors showed the students' were not able to put some preposition where something happens or they called preposition of place, and direction.

For example:

a) "Which lived ${ }^{\wedge}$ the palace...", instead of "Which lived in the palace..."

b) "He went $\wedge$ the jungle...," instead of "He went to the jungle...,"

c) "He felt $\wedge$ love at her..." instead of "He felt in love at her..."

There are 35 students made errors in insertion which the totals of error are 99 errors or $41.9 \%$. In this type, these errors showed that students were put some preposition were not needed.

For example:

a) "They were in happy family...," instead of "They were happy family..."

b) "Make a huge ship and large in lake at night..." instead of "Make a huge ship and large lake at night..."

c) "He kicked at the ship..." instead of "He kicked the ship..."

There are 35 students made errors in selection which error 64 errors or $27.1 \%$. these errors showed that students choosing of incorrect prepositions, the students confused put the appropriate preposition.

For example:

a) "Once getting at home" instead of "After getting at home" 
b) "You must give her front me." Instead of " You must give her to me"

"A bunch at cucumber seeds" instead of "A bunch of cucumber seeds"

\section{CONCLUSION}

Based on the explanation and the description in the previous chapter, the researcher concluded that the types of error that were made by the students of the eleventh grade students of SMK Tunas Karya Pekanbaru in their English writing from the highest percentage to the lowest were error of Insertion by percentage $41.9 \%$, errors of omission by percentage $30.9 \%$, and errors of selection by percentage $27.1 \%$.

Based on the findings from this research, it was expected for the teacher to give further corrections and clear explanations toward students' errors during learning process in learning grammar especially on the use of preposition. Moreover, the teacher should give the students more comprehension in writing and also putting the use of the right preposition. The teacher might really focus on the use of preposition especially in selection the right preposition since the finding of this research showed that the students did that type of errors the most in selection of preposition.

Then, it was expected for the students to practice more in using preposition in their composition especially in selecting the appropriate preposition. The students might do more exercise for making sure their comprehension in using preposition in their composition. Meanwhile, it would be better for the students to knowing the types of preposition in accordance with its use. It could improve the students' knowledge and also their skills in selecting the appropriate preposition when they write composition.

\section{REFERENCES}

Anderson, M. \& Anderson K. (2003). Text Types in English 2. South Yarra: Macmillan.

Anonymous. (2006). silabus ktsp (kurikulum tingkat satuan pendiidikan). jakarta: departemen pendidikan nasional.

Arjan A, Abdulla N, H \& Roslim N. (2013). english language teaching, a corpus based study on english preposition of place in and on.

Azar, B. S. (1999). Understanding and using English Grammar (3rd ed.).

Brown, H. Douglas. (1980). Principles of Language Learning and Teaching, fifth edition. New york: Longman.

Cholid Narbuko dan Abu Achmadi . (2013). Metode penelitian. jakarta: PT. Bumi Aksara.

Corder, S. P. (1981). Error Analysis and Interlanguage. britain: Oxford University Press.

Ellis, R. (1994). The Study of Second Language Acquisition. Oxford: oxford university press.

Ellis, R. (1997). Second Language acquisition. oxford: oxford university press.

Gaetz., Lynne., \& Phadke, S. (2011). The writer's world.

Hasanah, U. (2017). Error Analysis on Using Simple Present Tense in Writing Descriptive Text Made By The Tenth Grade Students of SMA N 1 Pace. artikel skripsi.

Hourani, Y. (2008, november 22th). An Analysis of The Common Grammatical Errors In The English Writing Made By Secondary Male Students In The Eastern (Disertation, Institute of 
Education. Retrieved from http://bspace.buid.ac.ae/bitstream/ 1234/225/1/20050055.pdf.

Jha, A. K. (1991). Errors in the use of prepositions by Maithili learners of English and their remedies. 5152.

Murshidi, G. (2014). The difficulties of UAE university students in the use of preposition. 173.

Mustafa, F., Kirana, M., \& Bahri, S. (2017). Errors in EFL writing by junior high students in Indonesia. International Journal of Research Studies in Language Learning, 49.

Learners. Journal of Language Teaching and Research. 149-156.

Khan, I. U. \& Karim, A. (2014). Strategies for improving English language Listening Skill (The Case of Distract Bannu). Research on Humanities and Social Sciences, 37-48.

Lipnevich, A. A. (2008). Response to Assessment Feedback:The Effects of Grades, Praise, and Source of Information. Educational Testing Service, 1-28.

Lipnevich, A. A. \& Smith, J. K. (2009). Effects of Differential Feedback on Students' Examination Performance. Journal of Experimental Psychology:

Applied, 319-333. 